\title{
In Search of a Suitable Model of Penal Code for Afghanistan ${ }^{1}$
}

\author{
Tun Abdul Hamid Mohamad*
}

\section{Historical Background}

During the Moghul rule of what now constitutes India, Pakistan, Bangladesh and Afghanistan, the courts there administered the Shariah to the exclusion of Hindu law. Islamic law gave way to English criminal law with the increase of British influence in the Indian sub-continent. Before 1860, English criminal law, as modified to suit local circumstances, was administered in the PresidencyTowns of Bombay, Calcutta and Madras. The draft of the Indian Penal Code was prepared by the First Law Commission, chaired by Thomas Babington Macaulay. Its basis is the law of England. Elements were also derived from the Napoleonic Code and from Edward Livingston's Louisiana Civil Code of 1825 . Finally, the Indian Penal Code was passed into law on 6 October 1860. The Code came into operation on 1 January 1862.

It is interesting to note that elements of the Napoleonic Code were also absorbed; if you read the introduction written by David Moussa Pidcock to "Napoleon and Islam", the English translation of Napoleon et l'Islam by Christian Cherfils, published in 1914, you will find that that $96 \%$ of the Code Napoleon came from the rulings of Imam Malik. (If there is some merit to this claim, it may well have to do with Napoleon's Egyptian campaign.)

After independence, the Indian Penal Code was inherited by Pakistan (now called Pakistan Penal Code) and (now) Bangladesh, formerly part of British India. It was also adopted wholesale by the British colonial authorities in Burma, Sri Lanka, Malaysia, Singapore and Brunei, and remains the basis of the criminal codes in those countries.

The adoption of the Penal Code transcended religion: Pakistan, Bangladesh, Brunei and Malaysia are not only Muslim-majority countries but also "Islamic" countries; Sri Lanka and Myanmar (formerly Burma) have Buddhism as their state religion, while Singapore is a modern cosmopolitan city-state.

Afghanistan defeated the British in the First Anglo-Afghan War (1839-1842). Even after the Second and the Third Anglo-Afghan Wars (1878-1880 and 1919, respectively) the British did not or could not succeed in colonising Afghanistan. Afghanistan escaped the introduction of Macaulay's Penal Code for over a century! 
Among the Islamic countries that inherited Macaulay's Penal Code from the British rule, Malaysia, now widely known as the world's most-advanced Islamic country and the leader in Islamic banking and finance, is happy to retain it as introduced save for unavoidable amendments necessitated by the variation in time and place. Bangladesh too seems to have made few changes to it. Brunei, in her quest to be Shariah-compliant, has been struggling for the past thirty years to "Islamise "the Penal Code with the help of a Pakistani former professor, but has yet to see the light at the end of the tunnel. On the other hand, Pakistan, where politics play a more powerful role than in Brunei, has gone further. It has Islamised the Penal Code.

Clearly, the aim was to replace the existing "un-Islamic law" or "law of the unbelievers" with the Shariah. One would think that the Penal Code would have been discarded and replaced with a totally new Islamic criminal law. That is the impression you get if you listen to the politicians and the preachers.

But if we look at the Pakistan Penal Code now, we note that Macaulay's Penal Code remains entirely intact: the name, language, structure, style, and a large portion of the contents are unchanged. That means it is not contrary to Shariah.

New sections were added to provide for the introduction of the Shariah punishments such as Qisas, Diyat, Arsh, Daman and Ta'zir (Section 53). There are major amendments in Chapter XVI "Of Offences Affecting The Human Body" and very lengthy provisions on causing hurt and the numerous types of punishments provided for each type.

Rather than comment on these Shariah provisions or compare them with the original Macaulay draft, I look to them for a model which could be used as the basis for a penal code that could be introduced to Afghanistan.

Reasons in support of this are as follows:

1. Had the British succeeded in colonising Afghanistan as they did over the Indian Sub-continent, Burma, Malaysia, Singapore and Brunei, most likely Macaulay's Penal Code would have been introduced into Afghanistan more than a century ago.

2. The Code has survived the test of time, most significantly in the Indian sub-continent which in many ways resembles Afghanistan. Though British India has since split into India, Pakistan, Bangladesh and Sri Lanka, the Code is still the law in those countries.

3. If Afghanistan is a predominantly Muslim country, so then are Pakistan, Bangladesh, Brunei and Malaysia.

4. If the majority of the people of Afghanistan now aspire to have the Shariah as their criminal law, Pakistan has enacted this within the Code itself while yet retaining the vast majority of the original provisions 
which certainly were seen to be "not contrary" to Shariah; otherwise they would have been repealed. Similar modifications may be made to suit circumstances in Afghanistan.

5. Afghanistan is closest to Pakistan, geographically, historically, demographically and culturally. The majority of the people of the two countries share not only the same religion but are also the followers of the same Hanafi school of Islamic jurisprudence. A large portion of the population of the two countries also shares the same language.

Thus there are sufficient reasons to use the Pakistan Code as the basis for the Afghan Penal Code, though it is necessary to find out what the Afghan people want, what the Afghan Government thinks necessary to effectively govern the country, and what lawyers think to be the provisions the Code should incorporate. If the Code still serves all the countries mentioned above, why not Afghanistan?

However, the following points should be taken into account:

1. First, the single most important factor to remember in making or adopting law is the attainment of justice. Law without justice is bad law and justice is universal. A law which turns a victim of rape into a criminal and requires punishment for adultery while the rapist goes free is an unjust law by any standard, whatever source is claimed for it.

2. Second, law is universal too. Whatever source is claimed, the net effect is mainly the same. Macaulay's Penal Code is said to be based partly on English law and partly on the Napoleonic Code and Edward Livingston's Louisiana Civil Code of 1825.

3. Third, any law, human or divine, so long as it is administered by men, may be abused and give way to injustice. There is a tendency among Muslims to assume that if they do something which they believe to be Islamic and in the name of Islam, everything will turn out fine: Allah s.a.w. will take care of everything. They forget that sunnatullah applies to all: you have to do the right thing to get the right result. They forget that even the Prophet and his troops lost the Battle of Uhud, not because of lack of piety or wavering faith, but because the archers deserted their positions and prematurely rushed for the spoils of war. It was a question of not following orders and lack of discipline. So, there have to be safeguards, wherever possible.

\section{Possible Resistance}

I believe that there will be groups who might resist the proposal on the ground that the Code comes from a non-Islamic source. But ask them to produce the 
"Islamic Code" and they would not be able to do so. We had a similar experience in Malaysia in 1980s when we were drafting the criminal and civil procedure codes. In the end, we took the Criminal Procedure Code which was used in the civil court as the basis; the Criminal Procedure Code came from India, and the same countries that adopted Macaulay's Penal Code also adopted the Criminal Procedure Code. Now this same Code with some modifications is known as the Shariah Criminal Procedure Act or Enactment. The same "non-Islamic" provisions have thus become Shariah. It was the same with the Civil Procedure law. We adopted the Subordinate Courts Rules used in the Subordinate Courts, made the necessary modifications, and now it is known as Shariah Civil Procedure Act or Enactment.

Even now, as Chairman of the Law Harmonization Committee, I do the same thing: identify the provisions which are not Shariah-compliant, ascertain the Shariah position and make the necessary amendment. The latest example is the provision regarding "interest after judgment" in the Rules of Court. We have added another provision which is Shariah-compliant and applicable to cases arising from transactions in accordance with Shariah, e.g. Islamic Banking transactions. The old provision continues to apply to all other cases. ${ }^{3}$

\section{Approach}

More than a decade ago, I was asked, "What is your definition of Islamic law?" My reply was "Any law that is not un-Islamic." I believe that here too, the same approach should be taken. Pakistan has done the same when Islamising her Penal Code. Why not extend the methodology to Afghanistan? Most of what needs to be done has been done by Pakistan.

I also believe that a law may be completely new yet Islamic; a law may be different from that at the time of the Prophet yet it can also be more Islamic. In my Abd Razzaq Al-Sanhouri Lecture at Harvard University, for the first proposition I gave the example of Road Traffic Law and for the second, a law regarding slavery. ${ }^{4}$

In adopting the Shariah, we should look for the principles, not the minute details and sub-divisions as the earlier jurists had done. For example, referring to the provisions regarding the offence of "hurt" (starting from section 332 until the end of Chapter XVI, in the Pakistan Penal Code), the Macaulay Penal Code divides "hurt" into two main categories: "hurt" and "grievous hurt". The Shariah provisions also contain numerous divisions and sub-divisions, each with a specific name and punishment. I pity the magistrate or the judge, who, having made a finding of facts before him, tries to slot it in into one of the many pigeonholes to arrive at judgment. I do not think anyone would say that it is God's injunction that it should be that way. 
Two factors influenced the work of traditional jurists: first, their love for dividing and sub-dividing something into different categories and sub-categories and giving each one of them a specific name; second, the Shariah punishment combining criminal punishment and civil liability. Note that the Macaulay Penal Code confines itself to criminal punishment only.

I think it worthwhile to reduce the categories and sub-categories of the offences of hurt and their respective sentences to introduce the Shariah alternative of the offence of hurt.

\section{Hudud}

Hudud is a matter of policy for a country to decide. However, I would like to make a few points that should be considered in making the decision.

First, I do not subscribe to the view that hudud is central to Islam, or that you must implement hudud to be Islamic. Within two decades from the death of Prophet Muhammad (p.b.u.h.), the Second Caliph of Islam, Umar Ibn Khattab, suspended the implementation of hudud when there was famine. That decision was clearly based on his ijtihad. Has "the door of ijtihad" closed since then?

In addition, I tend to believe that punishment is not the objective (maqsid) of a law. The objective of the law is the attainment of justice and the maintenance of law and order. Punishments are methods which may change according to circumstances. That has happened throughout human history.

Also, the experience in Pakistan regarding rape should serve as a lesson. The hudud offence of theft, for example, may not be the most serious of offences relating to property now. There is no way in which a thief could steal a bank together with all its branches and assets. But the whole bank could be bankrupted by criminal breach of trust, which is not a hudud offence. In such a case, is criminal breach of trust less serious than theft and the amputation of hand as punishment less serious than imprisonment?

I believe it is a myth to say, as we often hear, that if you introduce hudud, the crime rate will immediately fall due to the fear of the punishment and the country will become a safer place to live in. Why, even in the $21^{\text {st }}$ century, is there a country that introduces hudud but does not allow a woman to drive or leave the home without being accompanied by a man and without covering herself from head to toe? Has that nothing to do with safety? Do you think it is safer for a young woman dressed casually to walk in any town in Pakistan, Sudan or Saudi Arabia than in Sweden or Japan? In those countries that have introduced hudud, what are the chances of a rape victim lodging a report? She could even be killed by her own relatives for what is known as "honour killing." 
Finally, there is the issue about witnesses, particularly the disparity between the evidence of male and female witnesses. In Malaysia and in Brunei, at one time, both the Attorney General and the Solicitor General were women. Are we saying that the evidence of the Attorney General and the Solicitor General put together is only equal to the evidence of their office boy alone?

\section{Conclusion}

To conclude, I think we can take the Macaulay Penal Code as the basis to work on. For that purpose we can use Pakistan Penal Code.

- First, remove those provisions which are peculiar to Pakistan and not relevant to Afghanistan.

- Second, I am quite sure Shariah-compliance will be an issue. Convince the objectors that the bulk of the provisions are already Shariah-compliant even though they do not use Arabic words: any law that is not un-Islamic is Islamic.

- Third, if Shariah provisions as in the Pakistan Penal Code and even hudud were to be included, then in adopting them, the points that I have mentioned above should be considered and taken into account.

\section{Notes}

* Tun Abdul Hamid Bin Haji Mohamad read law at the University of Singapore and graduated with LL.B (Hon) in 1969, then joined the Malay Judicial and Legal Service for twenty one years in numerous capacities until his appointment in 2007 as the Chief Justice of Malaysia. He retired on 18 October 2008. Tun has served as Judge in all the courts in the country, Civil as well as Shari'ah, writing a total of 567 judgments on all aspects of law for the Superior Courts. He delivered the Abdul Razaq Al-Sanhouri Lecture at Harvard University in November 2008. Still active as Chairman of the Law Harmonizing Committee of Bank Negara Malaysia, and a member of the Shari'ah Advisory Council of Bank Negara and the Securities Commission, he is also a member of the Judicial Appointments Commission. In 2011 Tun was awarded an Honorary degree of Doctor of Philosophy in Shari'ah and Judiciary by Universiti Sains Islam Malaysia (USIM). He can be contacted at tunabdulhamid@gmail.com and http://www.tunabdulhamid.my.

1. Composed by the author, former Chief Justice of Malaysia, for the United Nations Office on Drugs and Crime: Workshop on Reforming the Penal Code of Afghanistan, held 5-9 November 2012, Kuala Lumpur, Malaysia.

2. Such terms are popular among Islamist politicians and preachers even in Malaysia. I believe we can find such people in any country with a significant Muslim population.

3. See "Late payment charge on judgment debts in financial transactions in accordance with Shariah" - www.tunabdulhamid.my. See also "Harmonization of Common Law and Shariah in Malaysia: A Practical Approach" - www.tunabdulhamid.my

4. Ibid., "Harmonization".

5. The difficulty in forwarding this kind of argument is that someone will say that the premise is not authentic. There is no way in which anyone can prove or disprove it. In the end it becomes a matter of opinion, whether to accept it as authentic or not. I am putting forward the argument only on the assumption that the premise is authentic. All these show that there had been differences of opinion throughout history and therefore, we too can form our own opinion over an issue. 